\title{
The Choice Between Public and Private Debt by Russian Companies at Different Stages of the Life Cycle
}

\section{Vladimir Rossokhin}

$\mathrm{PhD}$ (Economic Sciences), Associate Professor of Financial Management Department of $\underline{\text { ORCID }}$

E-mail: vrossohin@hse.ru

National Research University Higher School of Economics, Nizhny Novgorod, Russia

\section{Elena Ryabova}

$\mathrm{PhD}$ (Economic Sciences), Associate Professor of Financial Management Department $\underline{\text { ORCID }}$

E-mail: eryabova@hse.ru

National Research University Higher School of Economics, Nizhny Novgorod, Russia

Journal of Corporate Finance Research, Vol. 14, No. 1, pp. 20-28 (2020)

DOI: https://10.17323/j.jcfr.2073-0438.14.1.2020.20-28

Received 11 February 2020 | Peer-reviewed 17 March 2020 | Accepted 20 March 2020 


\section{The Choice Between Public and Private Debt by Russian Companies at Different Stages of the Life Cycle}

\section{Abstract}

The problems of formation of the company's capital structure to date have already been studied well. A large number of theoretical papers and empirical studies devoted to this issue have been published. However, managers are confronted not only with the question of the optimal balance between equity and debt capital, but also with the choice of debt structure in the presence of several of its sources, such as public and private debt. This is a new paradigm in corporate finance. On the one hand, companies are not always ready to issue listed securities at the initial stages of their activity. On the other hand, raising funds in open markets has several advantages. With the help of public debt, one can attract a sufficiently large amount of financial resources with a lower cost in comparison with private borrowing. At the same time, as a rule, the public debt is not secured by the assets in the proper amount.

According to the author's opinion, in dealing with this question, companies can take into account not only the current state of the company and its financial indicators, but also the stages of the life cycle, since each of them has its own development features. The purpose of this study is to analyze whether life cycle stages and other financial indicators of a company affect the choice of a source of borrowed capital (private or public debt), thereby to contribute to the development of this research direction. The objects of study are Russian companies. In the empirical part of the study, the binary choice model had been applied.

The sample size is 1,818 companies, the financial statements for three years were used. The stages of the organization's life cycle were calculated by the method of V. Dickinson. A number of control variables were also included in the model. The results of empirical analysis indicate that the company decides to issue public debt, regardless of the stage of the life cycle. This allows us to conclude that the company, when conceptually resolving the question about the structure of borrowed capital, relies on economic indicators such as profitability, size of the company, structure of assets and financial leverage. Understanding this fact can also help potential investors in making investment decisions to form conservative portfolios.

Keywords: borrowed capital, debt structure, public debt, private debt, stage of the life cycle of the company, choice of the debt structure, binary choice model

JEL classification: D15, D22, G31, G32 


\section{Introduction}

Capital structure formation remains a major problem in corporate finance management. F. Modigliani and M. Miller (1958) are considered to be the founders of this theory and their paper is up to now, to a greater or lesser degree, the starting point for many researches in this sphere [1]. There is quite a number of theoretical and empirical studies dedicated to the problems of search for the optimal balance between equity and debt capital, finding and testing the factors which influence their balance $[2 ; 3]$. However, at present the most pressing issue is the choice of the borrowed capital source which structure is more complicated and heterogeneous and consists of several elements.

For many modern companies debt financing is virtually the main source of business development. However, in spite of the long period of its functioning this tooling is constantly developing and improving by taking new forms and ways of raising funds accommodating itself to the dynamically developing market. There is a series of papers which prove the importance of the borrowed capital source depending on the company size, its duration and other parameters $[4 ; 5]$ etc. However, these papers are occasional, they use data from other countries and test mainly the choice between equity and debt capital. At the same time the number of researches dedicated to justification of the choice of the debt financing source, in particular for emerging capital markets, is almost negligible. Besides, the composition and structure of the debt capital differ in the researches rather significantly. For example, D. Denis and V. Mihov distinguish three sources of debt financing: bank private debt, nonbank private debt, public debt. The latter in this paper implies issue of debt securities [6]. A similar opinion was proposed in the paper by A.Marshall, L.McCann, P.McColgan [7]. A lot of researchers think that companies may raise debt capital by bond issuance, borrowing funds from banks and financial companies $[8 ; 9 ; 10]$. D.Rauh and A.Sufi give a wider classification of the debt issued by companies which comprises bank debts, bonds, private placement, convertible debt, debts against security of equipment and immovable property etc. [11]. K.Khan distinguishes six sources in the debt structure including without limitation long-term and short-term borrowings, secured and unsecured ones [4].

Further we will define two fundamental sources in the debt financing structure: private and public debt. Justification of their choice depends on the combination of factors of external and internal environment. This determined the topic of the present research.

\section{State of Knowledge}

Theoretical researches assign an important part to the debt source when decisions on the company capital structure are taken. According to the reputation theory, in D. Diamond's opinion, the companies first borrow and redeem private debts and repeat this procedure over and over again intentionally [12]. Acquiring and redeeming a private debt a company demonstrates to the market its financial capacities, ability to manage business thus creating a corresponding reputation in credit markets. Later on, this should result in reduction of the debt cost and after that the company starts acquiring public debts. Acquiring a bank debt has its benefits and drawbacks. As a rule, bank monitoring reduces the costs of information asymmetry for the companies which furnish less information to the market than the borrowers which use public debts. In this case credit institutions may analyze more thoroughly the financial and business operations of a company, control its money flows [13]. On the other hand, it is easier to reschedule a bank debt in case of money troubles because a bank has more information on the company's cashflows and investment opportunities which enables it to take a decision whether, for example, liquidation is the optimum resolution $[14 ; 15]$. Thus, the companies which wish to avoid an excessive bank control will try to acquire a public debt by issuing of bonds.

In their turn, Y.Altunbaş, A.Kara and D. Marques-Ibanez showed that large companies with a large financial leverage, a higher profit and bigger liquidating value choose, as a rule, syndicated credit. On the contrary, the companies with a lower debt and the ones perceived by the market as promising companies, with more opportunities for growth prefer the financing through corporate bonds. Syndicated credits are a preferable instrument when the companies are very large, profitable but have less opportunities for growth [16]. E.Morellec, P.Valta and A.Zhdanov obtained the results which confirm that the companies with more growth opportunities, higher ratings and bargaining power in case of a default, operating in more competitive markets and getting less credit offers are more likely to issue bonds [17].

The research made by C.Lin et all. indicates that the companies controlled by principal shareholders prefer financing of their operations using public debt instead of the bank one in order to avoid a thorough study of their business and to protect themselves from bank monitoring [18]. Quite opposite conclusions are given in the paper by S.Boubaker et all. Through the example of French companies the authors found out that dependence on the bank debt increases for the companies with multiple large shareholders. Moreover, the influence of MLS on the choice of debt is greater when agency problems between the controlling and minority shareholders are more serious [19].

A.Kreb, B.Eierle and I. Tsalavoutas in their paper reached the conclusion that there is a relation between investments used in the current year for R\&D and the choice by the company of the source of debt financing for the next year. First, the companies investing in R\&D in the current year tend to issue of bonds and do not incur private debts in the syndicated loans market the next year. Second, $\mathrm{R} \& \mathrm{D}$ investments of the current year influence the cost of debt by reducing it. The previous researches dedicated to the study of the consequences of investments in research and development in the debt market are focused 
exceptionally on American companies and thus are based on the conditions under which the R\&D discretionary capitalization cannot be observed [20].

A.Marshall, L.McCann and P.McColgan study the choice of the debt source between the public debt, syndicated bank loans, bilateral bank loans and nonbank private debt. On the basis of the selection of 400 nonfinancial companies for 2000-2012 the authors make the conclusion that larger companies borrow in the public debt markets more often. The companies which depend on banks borrow in the public debt markets less frequently and choose between the bank and nonbank private debt on the basis of the repayment period, security available to the creditors and other characteristic features of the company. These results are in line with the fact that the borrower's reputation is the principal factor which defines the debt source for the companies listed on the British stock exchange [7].

H.Chen and colleagues reached the conclusion that it is more likely that the companies with less allocable assets, less possibilities of opportunity application of capital outside of the company will borrow from banks rather than issue bonds. These conclusions accord with the fact that in case of a default risk or another unfavourable financial situation such companies will consider the opportunity of the bank debt restructuring instead of liquidation of assets in case of a default [5].

Accordingly, the problem of choice of the debt financing source is a currently topical managerial solution in the sphere of corporate finance. For example, K.Khan et all. found out that large Pakistan companies as well as small ones adopt a strategy of debt specification, however the reasons and factors are different [4].

In this regard we think that it is important to study the influence of the aggregate of financial determinants on the choice of the debt financing structure. Therein, in our opinion, the most interesting is the problem of making decisions on issue of bonds as public debt and analysis of the factors which influence such decision. In the authors' judgement, one of the significant factors which should be taken into account in this case is the stage of development of the company. In the considered researches the stage of development is defined using the time factor. $\mathrm{R}$. Cole uses the period during which a company conducts business with the same management as a regressor. Therein this variable is significant at a high level [21]. C.Chang considered the time factor as the period which passed from the listing date. In some regressions this variable is significant in some - not [22]. J.Ramalho and J. da Silva define duration as an important factor and test corresponding hypotheses. Therein this regressor is significant only for individual groups of firms in different regressions [23]. F.Matias and Z.Serrasqueiro used an empirical analysis and found out the significance of the company duration at a high level in case of a joint and short-term debt for the companies of all regions and the significance just for the companies from some regions in case of a long-term debt. It follows that duration of a company is an controversial factor which influences the capital structure choice [24].

However inasmuch as market relations in some countries emerged relatively recently the time from the registration and re-registration date in compliance with new requirements cannot always be considered the company duration. Taking into account these specifics identical values of this variable will be characteristic of the biggest part of the selection, thus distorting the results of the research.

In the modern economic theory one of the concepts describing the company development stage is the company life cycle theory. Numerous research works proved that while following the life cycle trajectories the company evolutionizes changing approaches to management and decision making, overcoming certain difficulties.

Besides, a different degree of uncertainty and unequal development and growth opportunities are characteristic of each stage. Accessibility of financial markets, investors is also different. At the "creation" stage a company is unknown or little-known and its opportunities for growth are unmanifest. It has a small market segment, has no credit rating and, as a rule, no collateral. All managerial, organizational and financial decisions are taken by the entrepreneur/owner.

At the "maturity" stage, on the contrary, the company already has a stable market and lean business processes, however, the influence of bureaucratization and agency conflicts on financial, investment and other management decisions increases. Reduction of the total cashflow is characteristic of this stage and it decreases the prospects of the company development. The owner already has a vague image of the real business environment. In this regard raising debt capital and choice of its type depend greatly not only on the cashflow which is difficult to predict and is incidental to all stages, the company financial standing but on the manager's confidence. So, M.Pfaffermayr and colleagues proved that levers of influence on the corporate capital structure change throughout its life cycle [25]. In some papers it is also shown that a company life cycle is the explanatory factor of its financing structure [26; 27]. Besides, there is still no answer to the question which parameter should be used to measure the company duration. M.Pfaffermayr understands duration as the time since the date of registration. The results of his research show that younger companies demonstrate higher debt ratios and face great difficulties with fund raising sources [25].

In this regard the authors of this paper admit use of the corporate life cycle stage as a variable characterizing the company development level because, on the one hand, legislative regulations have no influence on them and on the other - they show the true state of affairs. It is assumed that young companies which have no reputation borrow in the bank sector (private debt) more often and later, when they become more serious, achieve certain indicators including the market position and capitalization they may take a decision on issue of public debt. This approach is 
presented in the papers which consider certain aspects of business operation $[26 ; 27 ; 28]$. E.Suyono, S.Yarram and R.Riswan conducted a research verifying the significance of the life cycle stages of a company in relation to interconnection between the capital structure and the company performance indicators. It was established that the creation and growth stages play a moderately important role in increase of influence of the capital structure on the corporate operating results while at the maturity and slowdown stages influence of the capital structure on the company performance diminishes [29]. It should be noted that this factor was considered in the abovementioned researches only when analyzing the capital structure in totality. As for the debt capital structure, the influence of the life cycle stages on it has not been studied sufficiently.

In this research we will test whether the life cycle stage influences the choice of debt financing source (public and private debt). According to this the offered hypothesis is stated as follows:

H0: companies are more likely to issue public debt at more advanced stages of the life cycle.

\section{Methodology}

The choice problem justifies the use of binary logit model. The dependent variable $y$ assumes the value of 1 if the company issued bonds and 0 - otherwise.

The binary choice model may be represented using a latent variable

$$
\mathrm{y}_{\mathrm{i}}^{*}=\alpha+\beta \mathrm{LC}_{\mathrm{i}}+\gamma \mathrm{X}_{\mathrm{i}}+\varepsilon_{\mathrm{i}},
$$

where LC is the column vector of the life cycle for the company компании $\mathrm{i}$; $\mathrm{X}$ is the column vector for the control variables of the country $i ; \gamma$ is a corresponding row vector of parameters of control variables of the regression; $\beta$ is a row vector of the life cycle parameters.

Thus,

$$
y_{i}=1 \text { if } y_{i}^{*} \geq 0 y_{i}=0 \text { if } y_{i}^{*}<0 \text {. }
$$

In order to define the life cycle stages of a company the method of V.Dickinson is often used in researches because of deficit of available information [22; 23]. In this paper we in the same way distinguish three stages using V.Dickinson's method (creation, growth and maturity):

Creation (Stage_1), if OCF $<0$, ICF $<0$ and FCF $>0$.

Growth (Stage_2), if OCF $>0$, ICF $<0$ and FCF $>0$.

Maturity (Stage_3), if OCF $>0, \mathrm{ICF}<0$ and FCF $<0$.

Uncertainty / turbulence stages were not taken into consideration in the model. In this case, taking into account the component of the vector of the life cycle stages, equation (1) is presented as follows:

$$
\begin{aligned}
& \mathrm{y}_{\mathrm{i}}^{*}=\alpha+\beta 1 \times \text { Stage } 1_{\mathrm{i}}+\beta 2 \times \text { Stage } \_2{ }_{\mathrm{i}}+ \\
& +\beta 3 \times \text { Stage } 3_{\mathrm{i}}+\gamma \mathrm{X}_{\mathrm{i}}+\varepsilon_{\mathrm{i}}
\end{aligned}
$$

Therein if the company is at a certain life cycle stage its corresponding variable assumes the value of 1 while the variables which characterize other stages have the value of 0 .

\section{Control variables}

The authors presume that the indicators which determine the capital structure in general may influence the choice of the types of borrowing: private and public. So, S.Titman and R.Wessels used the following indicators as regressors: pledge value of assets, growth, industry affiliation, company size, profitability and some others [2]. R.Rajan and L.Zingales included the following in the basic regression as a dependent variable: the share of fixed assets in the company assets; market-to-book correlation (balance sheet assets after deduction of the book equity plus the market value of equity capital, and all the above is divided by the balance sheet assets); sales logarithm; profitability [3]. Similar indicators are presented in papers by other authors $[30 ; 31 ; 32]$. Using West European countries as an example K.Jõeveer distinguished four main factors which influence the choice of the capital structure: income, asset profile, assets logarithm, median value of the financial leverage in a certain industry [33]. In some studies a share of paid dividends is taken as a variable [31;34]. Summary statistics for the determinants of the capital structure taken as explicative variables is represented in the paper by F.Matias and Z.Serrasqueiro [24].

On the basis of review of these and other papers the following indicators were included as control variables.

- Return on assets (ROA) is a ratio of net income (loss) to the total cost of assets.

- Return on equity (ROE) is a ratio of net income (loss) to the amount of equity and reserves.

- Return on sales (ROS) is a ratio of net income (loss) to sales revenue.

- Company size (Log_Assets) is calculated as the base logarithm of assets.

- Dividend ratio (Div_Ratio) is calculated as a ratio of dividend payouts when distributing profits to the owners to net income (loss).

- Asset profile (Tangibility) is defined as a ratio of the difference between the noncurrent assets and intangible assets to total assets.

- Rate of growth (Growth) is defined as a ratio of the purchased items of fixed assets, income-bearing investments in tangible assets and intangible assets to total assets (balance-sheet total).

- Financial leverage (Leverage) is calculated as a ratio of short-term and long-term obligations to equity and reserves.

The regression also comprises dummy variables indicating a year (Y_2014, Y_2015, Y_2016) to control fixed effects.

\section{Database}

The database contains 4,226 observations. The number of companies amounts to 1,818 , accounting statements for 2014, 2015 and 2016 were used. The companies belong to various industry sectors (fuel and energy, transportation, trading, metallurgical and chemical industry, commu- 
nications, automobile, construction, food, pharmaceutical, housing and utilities sector, machinery and metal working, agriculture, aircraft industry etc.). There are 1,009 observations for the companies at the creation stage, 1,368 - for the ones at the growth stage and 1,849 - at the maturity stage. Descriptive statistics of the variables which are not slack ones is presented in table 1.

The obtained results (table 1) show that the average value of the return on assets (ROA) amounts to approx- imately $5 \%$, while the return on equity (ROE) exceeds $10 \%$. Consequently, companies raise a lot of borrowed funds in order to provide additional returns for the owners and this confirms the ratio of the borrowed capital and equity. On average the share of tangible assets (tangibility) in the balance-sheet total amounts to $48 \%$ although the selection comprises nonfinancial companies which are not characterized by this feature but have debt obligations.

Table 1. Descriptive statistics

\begin{tabular}{|c|c|c|c|c|c|}
\hline & Mean & Median & S.D. & Min & $\operatorname{Max}$ \\
\hline $\mathrm{ROA}$ & 0.04634 & 0.02855 & 0.1392 & -2.962 & 2.165 \\
\hline $\mathrm{ROE}$ & 0.1065 & 0.1379 & 2.852 & -66.15 & 51.96 \\
\hline ROS & -0.0998 & 0.0263 & 3.877 & -139.6 & 40.09 \\
\hline Log_Assets & 16.57 & 16.37 & 1.522 & 10.23 & 23.35 \\
\hline Div_Ratio & 0.2156 & 0 & 3.142 & -135.6 & 81.45 \\
\hline Tangibility & 0.4779 & 0.493 & 0.2795 & 0 & 0.9923 \\
\hline Growth & 0.06153 & 0.03267 & 0.08797 & 0 & 0.8953 \\
\hline Leverage & 10.35 & 1.948 & 64.69 & $-1,021$ & 961.1 \\
\hline
\end{tabular}

\section{Results and Conclusions}

The results of the empiric analysis are represented in table 2 .

On the basis of the existing data the proposed hypothesis was not confirmed. Consequently, we can make the conclusion that the probability that a company enters stock exchange in order to issue bonds does not depend on the life cycle stage. Moreover, the return on assets, the company size, asset profile and the financial leverage are significant factors.

Therein it should be noted that the chances of bonds issuing increase with decrease of the return on assets and advance of the financial leverage level. This may mean that public debt is more attractive for a company due to various reasons: lower interest rates, long loan term, no monitoring by credit institutions etc. The obtained results do not accord with the conclusions made in the paper by Y.Altunbaş, A.Kara and D.Marques-Ibanez [16], however, they confirm the conclusions of E.Fama [13], T.Chemmanur and P.Fulghieri [14], O. Yosha [15].

The company size has a positive impact on the probability of borrowing by issue of public debt and this is in line with the results obtained by A.Marshall, L.McCann and P.McColgan [7]. The company which issues bonds has certain issue and transaction costs and a significant part of them does not depend on the size of the issue. Consequently, the bigger the issue size the lower such unit costs are. In its turn, a small company which has no certain reputation yet is highly unlikely to place a bond issue which exceeds greatly the size of the assets with an expected yield to maturity.
The asset profile, namely a share of tangible assets, has also a positive impact on making a decision of bonds issue because most likely the company is interested in the bond buyers with a large share of noncurrent assets which, in their turn, may be the subject of pledge or guarantee of loans.

So, if a company is rather large, its financial leverage is significant, it has a large share of tangible noncurrent assets and its profitability decreases such company is highly likely to enter the bond market irrespective of its life cycle stage.

The obtained results do not contradict D.Diamond's theory [12] which contemplates significance of the borrower's reputation when entering the financial market, however, when taking decisions on the choice of the debt financing source it is reasonable if Russian companies' managers pay attention to the life cycle stages of companies because each company has its own characteristic features, risks and opportunities. Otherwise the existing strategy oriented toward disregard of the business development stages, in the authors' opinion, may result in an unfavourable financial situation in future.

At present large, less profitable Russian companies which already have large amounts of borrowed funds prefer the strategy of public debt increase, thus trying to reduce operational risks, minimize expenses of bond issue and costs of debt. This may be explained by specific features of the emerging financial market ready for the issuer's elevated risks as well as by the fact that companies are forced to look for a cheaper funding source when income is low or other factors which require an additional study. 
Table 2. Results of the empirical analysis

\begin{tabular}{|c|c|c|c|c|c|}
\hline & Coefficient & Statistical error & $\mathbf{Z}$ & P-value & $\begin{array}{l}\text { Marginal effect for } \\
\text { average }\end{array}$ \\
\hline Const & -9.61930 & 0.755777 & -12.73 & $4.15 \mathrm{e}-037^{\star * *}$ & \\
\hline Stage_1 & 0.0959031 & 0.193226 & 0.4963 & 0.6197 & 0.00386663 \\
\hline Stage_2 & 0.0713751 & 0.164069 & 0.4350 & 0.6635 & 0.00284465 \\
\hline $\mathrm{ROA}$ & -1.58607 & 0.454044 & -3.493 & $0.0005^{\star * *}$ & -0.0624773 \\
\hline ROE & 0.00859381 & 0.0169647 & 0.5066 & 0.6125 & 0.000338520 \\
\hline ROS & 0.0326664 & 0.0387466 & 0.8431 & 0.3992 & 0.00128677 \\
\hline Log_Assets & 0.363362 & 0.0447726 & 8.116 & $4.83 \mathrm{e}-016^{* * *}$ & 0.0143132 \\
\hline Div_Ratio & 0.00140074 & 0.0247533 & 0.05659 & 0.9549 & $5.51765 \mathrm{e}-05$ \\
\hline Tangibility & 0.809868 & 0.305741 & 2.649 & $0.0081^{\star * *}$ & 0.0319016 \\
\hline Growth & -0.891645 & 0.936959 & -0.9516 & 0.3413 & -0.0351229 \\
\hline Leverage & 0.00394032 & 0.000678087 & 5.811 & $6.21 \mathrm{e}-09^{* * *}$ & 0.000155214 \\
\hline Y_2014 & 0.168375 & 0.177193 & 0.9502 & 0.3420 & 0.00681454 \\
\hline Y_2015 & 0.149215 & 0.175598 & 0.8498 & 0.3955 & 0.00601961 \\
\hline
\end{tabular}

McFadden R square $=0.085764$.

Likelihood ratio criterion: chi-square $(12)=150.74[0.0000]$.

${ }^{\star * *}$ - significance at the $1 \%$ level; ${ }^{\star *}$ - significance at the $5 \%$ level; ${ }^{\star}$ - significance at the $10 \%$ level.

\section{Conclusion}

Summing up, we conclude that a company tends to take a decision of the public debt issue irrespective of the life cycle stage. It means that the degree of the business development and its possible opportunities for growth in future have no influence on the management's decision as regards debt specification and structuring from the point of view of its tooling. It indicates that a company may issue bonds taking into consideration only statutory restrictions instead of life cycle stages and their characteristics. This bears additional risks for investors.

It should be noted among positive aspects that Russian companies which issue and tend to issue public debt take into consideration not just the amount of the balance-sheet total but existence of physical long-term assets, which guarantee the obligations de facto, as well. On the other hand, the conducted research confirmed that the larger the share of the debt capital and the lower the profitability, the greater is the tendency to acquire public debt instead of the private one.

\section{References}

1. Modigliani F., Miller M.H. The Cost of Capital, Corporation Finance and the Theory of Investment. American Economic Review. 1958; 48: 261-297. https://www.jstor.org/stable/1809766

2. Titman S., Wessels R. The Determinants of Capital Structure Choice. The Journal of Finance. 1988; 43 (1): 1-19. DOI: 10.2307/2328319 https://www.jstor.org/ stable/2328319

3. Rajan R. G., Zingales L. What Do We Know about Capital Structure? Some Evidence from International Data. The Journal of Finance. 1995; 50 (5): 14211460. DOI: $10.2307 / 2329322$ https://www.jstor.org/ stable/2329322

4. Khan K. I., Qadeer F., Rizavi S. S. Reasons of Debt Specialization: Understanding the Perspectives of Small and Large Organizations. 2017. URL: http:// dx.doi.org/10.2139/ssrn.2957471 
5. Chen H., Maslar D. A., Serfling M. Asset

Redeployability and the Choice Between Bank Debt and Public Debt. Available at SSRN 3104096. 2018. doi: 10.2139/ssrn.3104096

6. Denis D. J., Mihov, V. T. The Choice Among Bank Debt, Non-Bank Private Debt, and Public Debt: Evidence from New Corporate Borrowings. Journal of financial Economics. 2003; 70(1): 3-28. doi:10.1016/ S0304-405X(03)00140-5

7. Marshall A., McCann L., McColgan P. The Choice of Debt Source by UK Firms. Journal of Business Finance \& Accounting. 2016; 43 (5-6): 729-764. https://doi. org/10.1111/jbfa.12194

8. Ključnikov A., Belás, J. Approaches of Czech Entrepreneurs to Debt Financing and Management of Credit Risk. Equilibrium. Quarterly Journal of Economics and Economic Policy. 2016; 11(2): 343-365. https://doi.org/10.12775/EQUIL.2016.016

9. Kraemer-Eis H., Lang F. Access to Funds: How Could CMU Support SME Financing? Vierteljahrshefte zur Wirtschaftsforschung. 2017; 86(1): 95- 110. https://doi.org/10.3790/vjh.86.1.95

10. Omoshagba T. P., Zubairu U. M. A Systematic Review of the Field of Debt Financing. Covenant Journal of Entrepreneurship. 2018; 1 (3): 34-49.

11. Rauh J.D., Sufi A. Capital Structure and Debt Structure. The Review of Financial Studies. 2010; 23 (12): 4242-4280. URL: http://dx.doi.org/10.2139/ ssrn. 1097577

12. Diamond D. W. Monitoring and Reputation: The Choice Between Bank Loans and Directly Placed Debt. Journal of political Economy. 1991; 99 (4): 689721. URL: https://www.jstor.org/stable/2937777

13. Fama E. What's Different About Banks? Journal of Monetary Economics. 1985; 15 (1): 29-39. https://doi. org/10.1016/0304-3932(85)90051-0

14. Chemmanur T. J., Fulghieri P. Reputation, Renegotiation, and the Choice Between Bank Loans and Publicly Traded Debt. Review of Financial Studies. 1994; 7: 673-692. https://www.jstor.org/ stable/2962265

15. Yosha O. Information Disclosure Costs and the Choice of Financing Source. Journal of Financial Intermediation. 1995; 4: 3-20. https://doi.org/10.1006/ jfin.1995.1001

16. Altunbaş Y., Kara A., Marques-Ibanez D. Large Debt Financing: Syndicated Loans Versus Corporate Bonds. The European Journal of Finance. 2010; 16 (5): 437-458. Doi: 10.1080/13518470903314394

17. Morellec E., Valta P., Zhdanov A. Financing Investment: The Choice Between Bonds and Bank Loans. Management Science. 2014; 61 (11): 25802602. https://doi.org/10.1287/mnsc.2014.2005
18. Lin C. et all. Corporate Ownership Structure and the Choice Between Bank Debt and Public Debt. Journal of Financial Economics. 2013; 109 (2): 517-534. URL: https://doi.org/10.1016/j.jfineco.2013.03.006

19. Boubaker S., Rouatbi W., Saffar W. The Role of Multiple Large Shareholders in the Choice of Debt Source. Financial Management (WileyBlackwell). 2017; 46 (1): 241-274. URL: https://ssrn. com/abstract $=2840452$

20. Kreß A., Eierle B., Tsalavoutas I. Development Costs Capitalization and Debt Financing. Journal of Business Finance \& Accounting. 2019. Doi: 10.1111/ jbfa.12370.

21. Cole R. A. What Do We Know about the Capital Structure of Privately Held US Firms? Evidence from the Surveys of Small Business Finance. Financial Management. 2013: 42 (4): 777-813. https://www. jstor.org/stable/43280515

22. Chang C., Chen X., Liao G. What are the Reliably Important Determinants of Capital Structure in China? Pacific-Basin Finance Journal. 2014; 30: $87-$ 113. https://doi.org/10.1016/j.pacfin.2014.06.001

23. Ramalho J., da Silva J. V. A Two-part Fractional Regression Model for the Capital Structure Decisions of Micro, Small, Medium and Large Firms. Quantitative Finance. 2009; 9 (5): 621-636. https:// doi.org/10.1080/14697680802448777

24. Matias F., Serrasqueiro Z. Are there Reliable Determinant Factors of Capital Structure Decisions? Empirical Study of SMEs in Different Regions of Portugal. Research in International Business and Finance. 2017; 40: 19-33. https://doi.org/10.1016/j. ribaf.2016.09.014

25. Pfaffermayr M., Stöckl M., Winner H. Capital Structure, Corporate Taxation and Firm Age. WIFO Working Papers. 2012; 424. URL: http://hdl.handle. net/10419/128973

26. Nidar S. R., Utomo R. A. P. Company Life Cycle and Capital Structure of Manufacturing Sector in the Consumer Goods Industry. Jurnal Bisnis dan Manajemen. 2017: 18 (1): 46-54. DOI: 10.24198/jbm. v18i1.43

27. Castro P. C., Tascón M. T., Amor-Tapia B. Dynamic Analysis of the Capital Structure in Technological Firms Based on the Firms'life Cycle Stages. Spanish Journal of Finance and Accounting/ Revista Española de Financiación y Contabilidad. 2015: 44 (4): 458486. URL: http://www.aeca1.org/pub/on_line/ comunicaciones_xviicongresoaeca/cd/24b.pdf

28. Juliana R., Suk K. S. Financial Flexibility, Life Cycle, and Capital Structure. Proceedings of International Conference and Doctoral Colloquium in Finance, Indonesia. 2017. URL: https://www.researchgate.net/ publication/324135698 
29. Suyono E., Yarram S. R., Riswan R. Capital Structure, Corporate Performance, and Life Cycle: Evidence from Indonesia. Corporate Ownership \& Control. 2017; 14(4-2). DOI: $10.22495 /$ cocv14i4c2art10

30. Delcoure N. The Determinants of Capital Structure in Transitional Economies. International Review of Economics and Finance. 2007; 16: 400-415. https:// doi.org/10.1016/j.iref.2005.03.005

31. Danis A., Rettl D. A., Whited, T. M. Refinancing, Profitability, and Capital Structure. Journal of Financial Economics. 2014; 114: 424-443. https://doi. org/10.1016/j.jfineco.2014.07.010

32. Booth L., Aivazian, V., Demirguc-Kunt A., Maksimovic V. Capital Structures in Developing Countries. The Journal of Finance. 2001; 56 (1): 87 130. https://www.jstor.org/stable/222464

33. Jõeveer K. What do We Know about the Capital Structure of Small Firms? Small Business Economics. 2013; 41 (2): 479-501. https://www.jstor.org/ stable/43552879

34. Sun J., Ding L., Guo J. M., Li. Y. Ownership, Capital Structure and Financing Decision: Evidence from the UK. The British Accounting Review. 2016; 48: 448-463. https://doi.org/10.1016/j.bar.2015.04.001

35. Ivashkovskaya, I.V. and Yangel, D.O. Organization life cycle and aggregate growth indicator. Korporativnye finansy = Journal of Corporate Finance Research. 2010; 1 (4): 97-110. https://doi.org/10.17323/j.jcfr.20730438.1.4.2007.97-110 